\title{
HUBUNGAN POLA ASUH ORANG TUA DENGAN PERILAKU AGRESI PADA REMAJA DI SMA 1 SARASWATI DENPASAR
}

\section{RELATIONSHIP BETWEEN PARENTING STYLE WITH AGGRESSIVE BEHAVIOR IN ADOLESCENT IN SARASWATI 1 HIGH SCHOOL DENPASAR}

\author{
Niken Ayu Merna Eka Sari ${ }^{1}$, Kiki Riski Fista Andriana ${ }^{2}$, Ni Ketut Ayu Mirayanti ${ }^{3}$ \\ ${ }^{1}$ Departemen Keperawatan Anak, Program Studi Keperawatan, STIKes Wira Medika Bali \\ ${ }^{2}$ Departemen Manajement, Program Studi Ners, STIKes Wira Medika Bali \\ ${ }^{3}$ Departemen Keperawatan Komunitas, Program Studi Ners, STIKes Wira Medika Bali
}

\begin{abstract}
ABSTRAK
Perilaku agresi remaja merupakan suatu keadaan emosi yang merupakan campuran perasaan frustasi dan benci atau marah. Hal ini didasari keadaan emosi secara mendalam dari setiap orang sebagai bagian penting dari keadaan emosional yang dapat diproyeksikan ke lingkungan, ke dalam diri atau secara destruktif. Salah satu faktor yang mempengaruhi perilaku agresi adalah pola asuh orang tua yang terbagi dalam tiga tipe, yaitu pola asuh otoriter, pola asuh permisif, dan pola asuh demokratis. Tujuan penelitian ini untuk mengetahui hubungan pola asuh orang tua dengan perilaku agresi pada remaja laki-laki madya. Sampel terdiri dari 129 responden dengan teknik simple random sampling. Pengumpulan data menggunakan kuesioner pola asuh orang tua dan perilaku agresi. Sampel terdiri dari 129 responden dengan teknik simple random sampling. Pengumpulan data menggunakan kuesioner pola asuh orang tua dan perilaku agresi. Hasil penelitian menunjukkan mayoritas pola asuh orang tua kategori pola asuh otoriter sejumlah $43,4 \%$, dan mayoritas perilaku agresi kategori tinggi sejumlah $48,1 \%$. Berdasarkan hasil uji korelasi rank spearman didapatkan hasip $\mathrm{p}$ value $=0,017<0,05$ maka Ho ditolak Ha diterima yang berarti terdapat hubungan tingkat kepecayaan diri dengan perilaku agresi. Kesimpulan ada hubungan antara pola asuh orang tua dengan perilaku agresi pada anak usia remaja di SMA Saraswati 1 Denpasar.
\end{abstract}

Kata Kunci: Pola asuh orang tua, perilaku agresi

\begin{abstract}
Adolescent aggressive behavior is an emotional state that is a mixture of feelings of frustration and hatred or anger. This is based on the emotional state in depth of each person as an important part of the emotional state that can be projected into the environment, inside or destructively. One of the factors thant influence aggressive behavior is parenting which is divided into three types, that are authoritarian parenting, permissive pareting, and democratic parenting. This research is to know relationship between the parenting style and aggression behavior of adolescent boys. The sample consisted of 129
\end{abstract}


Bali Medika Jurnal.

Vol 8 No 1, 2021: 45-50

DOI: https://doi.org/10.36376/bmj.v8i1

respondents with simple random sampling technique. Data collection using a questionnaire parenting style and aggression behavior. The results showed the majority parenting style in the authoritarian parenting category was $43.4 \%$, and the majority of the aggression behavior in the hight category was $48.1 \%$. Based on the Spearman rank correlation test results obtained $\mathrm{p}$ value $=0,017<0.05$ then Ho is rejected Ha is accepted, which means there is a relationship of parenting style with aggression behavior. Conclusion there is a relationship between parenting parents with aggressive behavior inadolescent in SMA Saraswati 1 Denpasar.

Keywords: Parenting Style, Aggression Behavior

\begin{tabular}{ll}
\hline Alamat Korespondensi & : Program Studi Keperawatan, STIKes Wira Medika Bali \\
Email & : nikenmerna@yahoo.co.id \\
\hline
\end{tabular}

\section{PENDAHULUAN}

Remaja mulai mencari identitas dirinya dengan mengadakan interaksi pada lingkungan sosialnya (Putri \& Abdurrohim, 2015). Proses pencarian identitas ini tidak selalu berjalan dengan lancar namun sering timbul emosi yang dapat diwujudkan dengan perilaku agresi (Hurlock, 2001:185). Berdasarkan penelitian yang dilakukan Masykouri (2005) di Amerika Serikat sekitar 5-10\% anak usia sekolah menunjukkan perilaku agresi. Anak laki-laki dan perempuan pada umumnya banyak menampilkan perilaku agresi baik perilaku agresi secara fisik, verbal maupun non verbal dan sebagainya (Mappiare, 2004:60). Komisi Perlindungan Anak Indonesia (KPAI) mencatat kasus tawuran di Indonesia meningkat 1,1\% sepanjang tahun 2018. Data kepolisian Polda Metro Jaya 2014 menunjukkan bahwa tindakan kekerasan yang dilakukan oleh para pelajar setiap tahun mengalami peningkatan, baik secara kuantitas maupun kualitas. Jenis kekerasan yang dilakukan oleh mereka cukup bervariasi, mulai dari pencurian, tawuran, perkelahian, pengroyokan, penganiayaan, sampai pembunuhan (Badan Pusat Statistik, 2014). Berdasarkan data di Polda Bali tahun 2018 sebanyak 12,87\% jumlah perilaku kekerasan pada remaja sedangkan sebanyak 3,4\% jumlah data enam bulan terakhir tahun 2019. Kasus perilaku agresi tertinggi kedua pada tahun 2018-2019 adalah Kota Denpasar, diantaranya perilaku kekerasan, penganiayaan dan pencurian, dimana pada kasus ini dikenakan hukuman sesuai dengan pasal 170 KUHP. Penyebab terjadinya agresi diantaranya dari faktor lingkungan, amarah dan pendisiplinan yang keliru sehingga individu yang melakukan perilaku agresi belum mampu mengontol dirinya. Faktor lingkungan salah satunya yaitu pola asuh orang tua (Septiari, 2012). Hasil penelitian yang dilakukan oleh Theresia Gustina Manalu (2010) yang berjudul Pola asuh orang tua dan perilaku agresi remaja di STM Raksana Medan dengan sampel penelitian sebanyak 50 remaja yang berperilaku agresi. Hasil penelitian diperoleh bahwa pola asuh orang tua paling banyak yang otoriter yaitu $86,0 \%$ dan paling sedikit dengan pola asuh permisif yaitu $14 \%$. Tindakan otoriter yang paling banyak disebabkan karena orang tua tidak pernah bersikap sabar dan ramah pada anaknya dan remaja seluruhnya berperilaku agresi (100\%). Berdasarkan data studi pendahuluan yang dilakukan di SMA Saraswati 1 Denpasar tahun ajaran 2018-2019 dengan teknik studi dokumentasi yaitu berupa 
laporan dari buku tahunan kesiswaan BK (Bimbingan Konseling). Sebanyak 42,6\% terjadi pelanggaran di kelas X dalam 10 kelas, sebanyak 30,9\% di kelas XI dalam 11 kelas dan sebanyak 55,1\% pada kelas XII dalam 10 kelas yang rata-rata kelas berjumlah 36 siswa. Pelanggaran yang dilakukan dengan jumlah yang paling tinggi diantaranya, bolos sekolah, melanggar seragam sekolah, pencurian helm dan uang, berkelahi antar teman, pengroyokan, lempar botol sesama teman dan ijin tanpa surat keterangan (alfa). Tujuan penelitian ini adalah untuk mengetahui hubungan pola asuh orang tua dengan perilaku agresi pada remaja laki-laki madya di SMA Saraswati 1 Denpasar. Hasil dari penelitian ini diharapkan dapat dijadian acuan bagi para guru di sekolah bahwa permasalahan-permasalahn yang dilakukan oleh remaja tidak semata-mata karena factor dari dirinya, namun ada factor pola asuh orang tua yang juga mempengaruhi hal tersebut sehingga tindakan yang dilakukan tidak hanya berfokus pada remaja itu sendiri namun juga harus melibatkan orang tua.

\section{METODE PENELITIAN}

Penelitian ini dilaksanakan di SMA 1 Saraswati Denpasar pada bulan Oktober 2019 - April 2020. Desain penelitian yang digunakan adalah penelitian deskriptif korelasi dengan pendekatan cross sectional. Populasi dalam penelitian ini semua siswa remaja laki-laki madya di SMA Saraswati 1 Denpasar yang berjumlah 192 orang. Sampel dalam penelitian ini adalah Remaja Laki-laki di SMA Saraswati 1 Denpasar yang memenuhi kriteria inklusi yaitu remaja laki-laki madya kelas XII dan Remaja laki-laki madya yang kooperatif dan bersedia menjadi responden dengan tehnik sampling probability sampling yaitu simple random sampling. Pengumpulan data dilakukan dengan menggunakan kuesioner pola asuh orang tua dan kuesioner perilaku agresi. Kuesioner pola asuh terdiri dari tiga komponen yaitu pola asuh demokratis, permisif dan otoriter. Pola asuh demokratis apabila pola asuh yang mengedepankan keseimbangan antara responsif dan perintah pada anaknya, permisif apabila pola asuh yang mengedepankan keseimbangan antara responsif dan perintah pada anaknya dan otoriter apabila gaya pengasuhan orang tua yang kental dengan pembatasan, pemaksaan pada anak untuk mengikuti aturan dan mematuhi kata-kata dari orang tua, mencoba untuk mengontrol anak secara penuh hingga adanya hukuman secara paksa pada setiap perilaku anak yang berlawanan dengan standar orang tua. Sedangkan kuesioner perilaku agresi diukur melalui kuesioner perilaku agresi remaja putra, yang terdiri dari 12 item pernyataan, dengan jawaban "tidak pernah diberi kode 1", "kadang-kadang diberi kode 2", "sering diberi kode 3", dan "selalu diberi kode 4" dengan indicator penilaian Perilaku agresi tinggi jika scor 31-48, sedang jika scor 21-30 dan rendah jika scor 10-20.

Pengukuran korelasi antara dua variable yang digunakan menganalisis hubungan antara variabel dengan skala nominal dan ordinal maka digunakan metode uji chi square menggunakan program komputer dengan derajat kemaknaan $\alpha=0,05(95 \%)$.

\section{HASIL DAN PEMBAHASAN}

Penelitian ini terdapat responden remaja madya laki-laki sejumlah 129. Karakteristik responden yang diteliti dilihat dari usia responden. Distribusi 
responden sesuai dengan karakteristik responden dapat dilihat pada tabel di bawah ini. Karakteristik responden berdasarkan umur terlihat pada tabel berikut :

Tabel 1

Distribusi Usia Responden di SMA Saraswati 1 Denpasar

\begin{tabular}{cccc}
\hline No & Usia & Frekuensi & Persentase (\%) \\
\hline 1. & 16 & 6 & 4,7 \\
2. & 17 & 99 & 76,7 \\
3. & 18 & 24 & 18,6 \\
\hline & Total & 129 & 100,0 \\
\hline
\end{tabular}

Berdasarkan tabel 4.1 didapatkan sebagian besar responden berusia 17 tahun sejumlah 99 orang $(76,7 \%)$.

\section{Hasil pengamatan terhadap obyek penelitian berdasarkan variabel penelitian \\ Pola Asuh Orang Tua}

Tabel 2

Distribusi Pola Asuh Orang Tua di SMA Saraswati 1 Denpasar

\begin{tabular}{clccc}
\hline No & \multicolumn{2}{c}{ Pola Asuh Orang Tua } & Frekuensi & Persentase (\%) \\
\hline 1. & Otoriter & & 56 & 43,4 \\
2. & Permisif & & 37 & 28,7 \\
3. & Demokratis & & 36 & 27,9 \\
\hline & & Total & 129 & 100,0 \\
\hline
\end{tabular}

Berdasarkan tabel 4.2 didapatkan bahwa pola asuh orang tua di SMA Saraswati 1 Denpasar adalah kategori otoriter sejumlah 56 orang $(43,4 \%)$

Perilaku agresi

Tabel 3

Distribusi Perilaku Agresi di SMA Saraswati 1 Denpasar

\begin{tabular}{ccccc}
\hline No & & Perilaku Agresi & Frekuensi & Persentase (\%) \\
\hline 1. & Tinggi & & 62 & 48,1 \\
2. & Sedang & & 47 & 36,4 \\
3. & Rendah & & 20 & 15,5 \\
\hline & & Total & 129 & 100,0 \\
\hline
\end{tabular}

Berdasarkan tabel diatas didapatkan bahwa sebagian besar perilaku agresi responden di SMA Saraswati 1 Denpasar adalah kategori sedang sejumlah 65 orang $(50,4 \%)$.

Hubungan pola asuh orang tua dengan perilaku agresi pada remaja laki-laki madya

Tabel 4

Hubungan Pola Asuh Orang Tua dengan Perilaku Agresi pada Remaja Laki-laki Madya di SMA Saraswati 1 Denpasar

\begin{tabular}{|c|c|c|c|c|c|c|c|c|c|c|}
\hline \multirow[t]{3}{*}{ No } & \multirow[t]{3}{*}{ Pola Asuh } & \multicolumn{6}{|c|}{ Perilaku Agresi } & \multirow{2}{*}{\multicolumn{2}{|c|}{ Total }} & \multirow{3}{*}{ P value } \\
\hline & & \multicolumn{2}{|c|}{ Tinggi } & \multicolumn{2}{|c|}{ Sedang } & \multicolumn{2}{|c|}{ Rendah } & & & \\
\hline & & $\mathbf{F}$ & $\%$ & $\mathbf{F}$ & $\%$ & $\mathbf{F}$ & $\%$ & $\mathbf{F}$ & $\%$ & \\
\hline & Orang Tua & & & & & & & & & \\
\hline 1. & Otoriter & 34 & 26,3 & 19 & 14,7 & 3 & 2,3 & 56 & 43,3 & \multirow{5}{*}{0,017} \\
\hline 2. & Permisif & 16 & 12,4 & 8 & 6,2 & 13 & 10,02 & 37 & 28,8 & \\
\hline 3. & Demokratis & 12 & 9,3 & 20 & 15,5 & 4 & 3,1 & 36 & 27,9 & \\
\hline \multirow[t]{2}{*}{4.} & & & & & & & & & & \\
\hline & Total & 62 & & 47 & & 20 & & 129 & 100 & \\
\hline
\end{tabular}


Bali Medika Jurnal.

Vol 8 No 1, 2021: 45-50

DOI: https://doi.org/10.36376/bmj.v8i1

Berdasarkan tabel 4.4 diperoleh hasil gambaran dari 129 responden sebagian besar memiliki pola asuh orang tua pada kategori otoriter dan perilaku agresi tinggi yaitu sejumlah 34 orang $(26,3 \%)$.

\section{Diskusi Hasil}

Pola asuh orangtua yang merupakan suatu bentuk pendidikan yang pertama kali diterima oleh anak. Lingkungan keluarga adalah lingkungan dimana anak pertama kali bersosialisasi. Hasil sosialisasi ini selanjutnya akan berdampak positif yaitu diterimanya pesan dengan baik, sehingga anak akan cenderung memberi umpan balik dari apa yang diajarkan orangtuanya. Apabila pendidikan pertama tersebut mengajarkan tentang adanya sikap otoriter, yang menunjukkan adanya kekakuan serta sikap ketat dari perlakuan pola asuh orang tua terhadap anak, anak akan cenderung mengingat dan melakukan peniruan sebagaimana yang ditunjukan orangtua, yaitu anak akan bersikap melakukan perlawanan disiplin, bersikap mementingkan diri sendiri, sikap mengunggulkan diri sendiri serta melakukan pertahanan diri. Hal ini terjadi karena interaksi sosial antara orang tua yang menerapkan pola asuh otoriter kepada anaknya menghasilkan suatu proses imitasi atau peniruan yang dilakukan oleh anak, sehingga anak perilaku agresi. Selain itu, temuan penelitian tersebut dapat dijelaskan oleh adanya pola asuh otoriter orangtua yang suka menerapkan pemberian hukuman fisik akan menyebabkan anak mempunyai sifat pemarah dan untuk sementara ditekan karena norma sosial (barier), namun suatu saat anak akan melupakan amarahnya sebagai perilaku yang agresi (Aisyah, 2010). Menurut Ernawati (2012), perilaku fisik maupun verbal yang diniatkan untuk melukai objek sasaran agresi, sebuah perilaku dapat dikategorikan sebagai perilaku agresi jika terdapat niat dan harapan untuk menyakiti atau merusak objek agresi serta adanya keinginan objek untuk menghindari agresi yang ditujukan kepadanya. Agresi seringkali berhubungan erat dengan marah. Ketika seseorang marah, biasanya ada perasaan ingin menyerang, memukul, menghancurkan atau melempar sesuatu dan biasanya timbul pikiran yang kejam. Bila hal-hal tersebut disalurkan maka terjadilah perilaku agresi.

Hal ini sesuai dengan penelitian yang dilakukan oleh Dwi Karunia Saputra dan Dian Ratna Sawitri (2015) dimana terdapat hubungan antara pola asuh orang tua dengan perilaku agresif pada remaja pertengahan di SMK Hidayah Semarang. Pentingnya faktor keluarga untuk dipertimbangkan ketika menyoroti agresivitas pada remaja dikemukakan oleh (Parasayu, 2018), yang mengatakan bahwa orang tua yang sering memberikan hukuman fisik pada anaknya dikarenakan kegagalan memenuhi standar yang telah ditetapkan oleh orang tua. Hal ini membuat anak marah dan kesal kepada orang tuanya tetapi anak tidak berani mengungkapkan kemarahannya dan melampiaskannya kepada orang lain dalam bentuk perilaku agresif. Orang tua yang terlalu menuntut membuat anak menjadi frustrasi.

\section{SIMPULAN DAN SARAN}

Berdasarkan hasil penelitian ini dapat disimpulkan bahwa terdapat hubungan antara pola asuh orang tua dengan perilaku agresi pada remaja laki-laki madya di SMA Saraswati 1 Denpasar. Hal itu disebabkan karena lingkungan keluarga merupakan lingkungan dimana anak pertama kali bersosialisasi. Sosialisai sosial 
antara orang tua yang menerapkan pola asuh otoriter kepada anaknya menghasilkan suatu proses imitasi atau peniruan yang dilakukan oleh anak, sehingga anak melakukan perilaku agresi. Oleh karena itu disarankan bagi orang tua agar mampu menerapkan pola asuh yang tepat sesuai kebutuhan anak.

\section{UCAPAN TERIMA KASIH}

Terima kasih kami sampaikan kepada Bapak Ketua STIKes Wira Medika Bali karena telah memberikan kami kesempatan untuk dapat melakukan penelitian di kampus tercinta ini. Serta terima kasih juga kami ucapkan atas dukungannya kepada pihak-pihak yang tidak dapat kami sebutkan satu persatu sehingga penelitian ini dapat terselesaikan dengan baik dan lancer.

\section{DAFTAR PUSTAKA}

Aisyah, S. (2010). Pengaruh Pola Asuh Orang Tua Terhadap Tingkat Perilaku Agresif Anak. Jurnal MEDTEK, 2(1), 1-7.

Badan Pusat Statistik. (2014). Proporsi Penduduk Yang Menjadi Korban Kejahatan Kekerasan Dalam 12 Bulan Terakhir Menurut Klasifikasi Wilayah. Retrieved from sirusa.bps.go.id website: https://sirusa.bps.go.id/sirusa/index.php/indikator/1657

Ernawati. (2012). Konsep dan Aplikasi Keperawatan dalam Pemenuhan Kebutuhan Dasar Manusia (A. Rifai, Ed.). Jakarta: Trans Info Media.

Hurlock. (2001). Psikologi Perkembangan (5 ${ }^{\text {th }}$ ed.). Jakarta: Erlangga.

Manalu, T. G. (2010). Pola asuh Orang Tua dan Perilaku Agresi Remaja di STM Raksana Medan. Universitas Sumatera Utara.

Mappiare, A. (2004). Psikologi Remaja. Surabaya: Usaha Nasional.

Masykouri. (2005). Faktor Penyebab Anak Berperilaku Agresif. Retrieved from BelajarPsikologi.com website: http://www.belajarpsikologi.com

Parasayu, Z. (2018). Hubungan antara Konformitas dan Perilaku Agresif pada Remaja. Universitas Islam Indonesia.

Putri, C. M., \& Abdurrohim. (2015). Hubungan antara Kematangan Emosi dengan Perilaku Agresi pada Siswa SMK Dinamika Kota Tegal. Jurnal Psikologi Proyeksi, 10(1).

Saputra, D. K., \& Sawitri, D. R. (2015). Pola Asuh Otoriter Orang Tua dan Agresivitas pada Remaja Pertengahan di SMK Hidayah Semarang. Jurnal EMPATI, 4(4), 320-326.

Septiari, B. B. (2012). Mencetak Balita Cerdas Dan Pola Asuh Orang Tua. Yogyakarta: Nuha Medika. 